\title{
Self-medications with potential abuse in the Middle East: a systematic literature review
}

\author{
Malak M. Khalifeh ${ }^{1,2}$, Nicholas D. Moore ${ }^{1}$, Pascale R. Salameh ${ }^{2}$
}

\author{
${ }^{1}$ INSERM U 1219 - Pharmaco- \\ epidemiology, University of \\ Bordeaux, Bordeaux, France \\ ${ }^{2}$ Department of Clinical and \\ Epidemiological Research \\ Laboratory, Faculty of \\ Pharmacy, Lebanese University, \\ Beirut, Lebanon \\ Received: 21 August 2016 \\ Revised: 27 August 2016 \\ Accepted: 03 October 2016 \\ *Correspondence to: \\ Dr. Malak M. Khalifeh, \\ Email: malak.9@hotmil.com \\ Copyright: () the author(s), \\ publisher and licensee Medip \\ Academy. This is an open- \\ access article distributed under \\ the terms of the Creative \\ Commons Attribution Non- \\ Commercial License, which \\ permits unrestricted non- \\ commercial use, distribution, \\ and reproduction in any \\ medium, provided the original \\ work is properly cited.
}

\begin{abstract}
Self-medication (SM) is highly prevalent in the Middle East. However, regulations in the Middle East are not always enforced and therefore many prescription medicines can be purchased as SM, resulting in potential abuse of many medicines. The aim of this article, therefore, was to undertake a comprehensive review to identify the different types of self-medications involved in abuse in the Middle East and to identify harms related to SM abuse. An extensive review of the published literature pertaining to the subject (1990 2015) was conducted using PubMed, Web of Science, Cochrane and Google Scholar databases for OTC medication abuse in the Middle East. Twenty two papers were identified. Medications involved in SM abuse included: psychoactive prescription-only medicines, codeine-containing products, tramadol, anabolic steroids, sedative antihistamines, decongestants and laxatives. Moreover, studies in the region rarely reported harms related to SM abuse and strategies to limit this abuse. Potential SM abuse involving a range of medicines is a public health problem in the Middle East. Future interventions and regulations should be applied to limit the expansion of SM use and potential abuse.
\end{abstract}

Keywords: Abuse, Middle East, Over-the-counter, Self-medication

\section{INTRODUCTION}

Regulations usually distinguish between prescription only (POM) and over-the-counter (OTC) medicines. The former require medical prescription and the latter are available for self-medication (SM) without a prescription from the physician. ${ }^{1}$ Globally, SM is reported as being on the rise due to the shift of many prescription medications to OTC. ${ }^{2}$ In the Middle East, self-medication is highly prevalent since regulations are not enforced in many countries and some prescription drugs are easily available as SM. Both OTC and POM medicines may thus be available for self-medication.

Self-medication has a potential to cause undue risk, addiction and dependency. Abuse is defined as the nonmedical use of medicines, e.g. to experience a 'high' or to lose weight. $^{3}$ A number of specific medicines and therapeutic groups have been implicated in literature including: cough syrups containing dextromethorphan or pseudoephedrine, opiate-based OTC analgesics, diphenhydramine and other antihistamines, sleeping aids, laxatives, anabolic steroids and other legally obtained medications ${ }^{4}$. Some of these may be obtained OTC, most will be POM, but may be dispensed without a prescription in some circumstances, and both may result in abuse.

This includes the non-medical use of psychoactive prescription medications, which may also be dispensed without prescription in the community pharmacy. Nonmedical use has been defined as use of these medicines without a doctor's prescription, or for longer periods than prescribed, or for reasons other than the drug's intended medical purpose (e.g., to get a "high").

However, there is a lack of quantitative data on abuse of non-prescribed medications by patients in the Middle 
East. There has been relatively little systematic research on this topic. It is limited to only one review article that has described the current knowledge and understanding of OTC medication abuse. ${ }^{6}$ Therefore, this article aims to undertake a comprehensive review to identify the different types of self-medication involved in abuse in Middle East Area. Other objectives were to identify the characteristics of those affected, harms associated with medication abuse and also interventions designed to deal with it.

\section{METHODS}

\section{Search strategy}

The initial PubMed and Web of science search was performed using the using combinations of the following terms: "over the counter", "OTC", "non-prescription", "self-medication", "prescription drugs", "abuse", "addiction", "dependency" and "nonmedical use", and a series of terms ensuring inclusion of all global and regional SM epidemiology publications. Publications from Arab and countries belonging to the WHO Eastern Mediterranean Region (EMRO) were searched (Table 1). Manuscripts in English, French, and Arabic languages were included and years were restricted to 1990 to 2007 with no age limits applied. Additional searches in the Cochrane Library and other sources from other reviews were used to identify peer-reviewed papers dealing with the review theme in WHO Eastern Mediterranean countries. Reviews were used for reference mining but they were not included. ${ }^{4,6,7}$

From the initial list of studies produced by the electronic search, a smaller subset was included for coding if the abstract met the selection criteria cited above. The first stage of inclusion was based on screening titles and abstracts. Specifically, titles and abstracts were included if the study was related to self-medication abuse or nonmedical use behavior. Articles related to alcohol or substance (other than medication) abuse or prescribed medications were excluded; although they represent an important category, they cover objectives different from those of the review theme related to SMs. Studies were also excluded via search limits if they were: review articles; carried out on animal models; hospital-based; clinical and/or randomized controlled trials; editorials, letters, opinions or comment publication type. Finally, full text articles were reviewed and assessed to determine whether inclusion criteria were met. Full-text reviews were also conducted on review articles to identify additional articles from their bibliographies.

\section{Data extraction}

The following details were extracted from each study using an extraction form that included the following: year of publication, country of origin, population sampled, recall period, and data pertaining to the study objectives.

\section{RESULTS}

Table 1: Search terminology used in literature review.

\begin{tabular}{|c|c|}
\hline Connector & Search Term [Text Word] \\
\hline & SM \\
\hline OR & OTC \\
\hline OR & Over the counter \\
\hline OR & Self-prescription \\
\hline OR & Non-prescription Drugs \\
\hline OR & Prescription Drugs \\
\hline \multicolumn{2}{|l|}{ AND } \\
\hline & Misuse \\
\hline OR & Abuse \\
\hline OR & Dependence \\
\hline OR & Addiction \\
\hline OR & Inappropriate use \\
\hline OR & Irrational Use \\
\hline OR & Nonmedical Use \\
\hline \multicolumn{2}{|l|}{ AND } \\
\hline & Eastern Mediterranean Countries \\
\hline OR & Middle East \\
\hline OR & Arab \\
\hline OR & GULF \\
\hline OR & Developing Countries \\
\hline OR & Lebanon \\
\hline OR & Jordan \\
\hline OR & Palestine \\
\hline OR & Iraq \\
\hline OR & Syria \\
\hline OR & Iran \\
\hline OR & Qatar \\
\hline OR & Saudi Arabia \\
\hline OR & Emirates \\
\hline OR & Kuwait \\
\hline OR & Yemen \\
\hline OR & Oman \\
\hline OR & Bahrain \\
\hline OR & Egypt \\
\hline OR & Libya \\
\hline OR & Sudan \\
\hline OR & Tunisia \\
\hline OR & Pakistan \\
\hline OR & Somalia \\
\hline OR & Djibouti \\
\hline OR & Afghanistan \\
\hline OR & Morocco \\
\hline
\end{tabular}

\section{Literature search results}

From the initial electronic search 696 papers were identified. After an abstract review, the most relevant abstracts were identified and full texts were reviewed. The Middle East produced 134 papers. Following secondary screening which involved reviewing the full papers to confirm that the paper strictly met the inclusion 
criteria, 112 papers were eliminated, leaving 22 papers, which were included (Figure 1). These studies reported on data collected from 1990 to 2015.

Table 2: Self-medication implicated in abuse.

\begin{tabular}{|c|c|c|c|c|c|}
\hline Country & Reference & Evaluated drug & Study design & Participants & Results \\
\hline Jordan & 15 & $\begin{array}{l}\text { Anabolic } \\
\text { steroids }\end{array}$ & $\begin{array}{l}\text { CS, self- } \\
\text { administered } \\
\text { questionnaire }\end{array}$ & $\begin{array}{l}353 \\
\text { participants } \\
\text { in Gym } \\
\text { clubs }\end{array}$ & $\begin{array}{l}31(8.8 \%) \text { clients admitted to using } 21 \text { products } \\
\text { (mentioned } 71 \text { times) of anabolic steroids and other } \\
\text { hormones (e.g., growth hormone and thyroxine) to } \\
\text { increase muscular power at the gym or build muscle } \\
\text { mass. }\end{array}$ \\
\hline Jordan & 1 & $\begin{array}{l}\text { Misuse and } \\
\text { Abuse of OTC } \\
\text { and prescription } \\
\text { drugs }\end{array}$ & $\begin{array}{l}\text { CS, self- } \\
\text { administered } \\
\text { questionnaire }\end{array}$ & $\begin{array}{l}393 \\
\text { pharmacists }\end{array}$ & $\begin{array}{l}\text { Most respondents }(94.1 \%) \text { suspected that some level of } \\
\text { abuse/misuse occurred in their pharmacy, which was } \\
\text { highest for decongestants, cough/cold preparations, } \\
\text { benzodiazepines, and antibiotics. }\end{array}$ \\
\hline Palestine & 12 & OTC & $\begin{array}{l}\text { CS, self } \\
\text { administered } \\
\text { questionnaire }\end{array}$ & $\begin{array}{l}97 \\
\text { pharmacists }\end{array}$ & $\begin{array}{l}2 / 3 \text { of respondents perceived an increase in suspected } \\
\text { OTC misuse or abuse due to instability in region, and } \\
\text { that majority was not regular customers. } 80 \% \text { of } \\
\text { pharmacists identified antitussives as being of } \\
\text { misuse/abuse potential, } 70 \% \text { identified analgesics, } 41 \% \\
\text { antihistamine problems and } 67 \% \text { laxative misuse/abuse. } \\
\text { Male customers were perceived more likely to abuse or } \\
\text { misuse OTC medications in all categories except } \\
\text { laxatives and the } 20-40 \text { age range was most commonly } \\
\text { identified. Informing the customer's doctor, hiding } \\
\text { products and informing customers of abuse potential } \\
\text { were identified as strategies to reduce problem. }\end{array}$ \\
\hline Egypt & 20 & $\begin{array}{l}\text { Psychoactive } \\
\text { médications: } \\
\text { sédatives and } \\
\text { tranquilliser }\end{array}$ & CS, survey & $\begin{array}{l}2187 \\
\text { households }\end{array}$ & $\begin{array}{l}\text { Of } 2170 \text { households with biological samples tested, } 247 \\
(11 \cdot 4 \%) \text { tested positive for any drug. Overall, opioids } \\
\text { were the most prevalent drug in the biological samples } \\
(5 \cdot 6 \%) \text {, although prescription drugs (prescription pain } \\
\text { pills, sedatives, and tranquillizer) were the most } \\
\text { commonly reported in the past } 30 \text { days in the } \\
\text { questionnaires }(7 \cdot 6 \%) \text {. After controlling for age with } \\
\text { direct standardization, individual prevalence of } \\
\text { substance use (from laboratory tests) was } 7 \cdot 2 \%(95 \% \text { CI } \\
6 \bullet 1-8 \cdot 3) \text { in men and } 3 \cdot 1 \%(2 \cdot 5-3 \cdot 7) \text { in women-with a } \\
\text { national prevalence of } 5 \cdot 1 \%(4 \cdot 4-5 \cdot 8) \text { and a prevalence } \\
\text { of } 5 \cdot 0 \%(4 \cdot 1-5 \cdot 8) \text { in Kabul. }\end{array}$ \\
\hline Egypt & 10 & $\begin{array}{l}\text { Psychoactive } \\
\text { medications: }\end{array}$ & $\begin{array}{l}\text { Qualitative } \\
\text { study }\end{array}$ & $\begin{array}{l}40 \\
\text { adolescents } \\
\text { from } \\
\text { community }\end{array}$ & $\begin{array}{l}\text { Our findings suggest that: (1) youth in Egypt had access } \\
\text { to and were actively using substances encountered in } \\
\text { similar research worldwide, including tobacco, alcohol, } \\
\text { illicit drugs, glue sniffing, and pharmaceutical agents; (2) } \\
\text { smoking cigarettes and using hashish were the most } \\
\text { common practices, and Tramadol was the most } \\
\text { commonly used pharmaceutical drug; (3) peer pressure } \\
\text { from friends stood out as the most common reason to } \\
\text { start and continue using substances, followed by adverse } \\
\text { life events and having a parent or family member who } \\
\text { used substances; Over the counter medications like } \\
\text { cough syrup were mentioned occasionally and only by } \\
\text { boys. }\end{array}$ \\
\hline Lebanon & 17 & $\begin{array}{l}\text { Psychoactive } \\
\text { substances }\end{array}$ & $\begin{array}{l}\mathrm{CS}, \\
\text { standardized } \\
\text { questionnaire }\end{array}$ & $\begin{array}{l}14656 \\
\text { secondary } \\
\text { school } \\
\text { pupils }\end{array}$ & $\begin{array}{l}\text { Among the reported results the following are deemed of } \\
\text { special interest: (1) Percentages of arts students who } \\
\text { smoke tobacco, ever use prescription psychotropic } \\
\text { substances, narcotics and alcohol consistently exceed } \\
\text { their counterparts studying science and mathematics. (2) } \\
\text { Ages of onset for the whole menu of substances range } \\
\text { between } 12 \text { and } 16 \text { years. More users than non-users tend } \\
\text { to see drug consumption as either harmless or even } \\
\text { useful. }\end{array}$ \\
\hline Lebanon & 18 & $\begin{array}{l}\text { Psychoactive } \\
\text { medications: }\end{array}$ & $\begin{array}{l}\text { CS, self- } \\
\text { administered } \\
\text { questionnaire }\end{array}$ & $\begin{array}{l}570 \\
\text { University } \\
\text { students }\end{array}$ & $\begin{array}{l}\text { Lifetime medical and nonmedical prevalence of } \\
\text { medications were (respectively): pain }(36.9 \%, 15.1 \%) \text {, } \\
\text { anxiety }(8.3 \%, 4.6 \%) \text {, sleeping }(6.5 \%, 5 / 8 \%) \text { and }\end{array}$ \\
\hline
\end{tabular}




\begin{tabular}{|c|c|c|c|c|c|}
\hline & & & & & $\begin{array}{l}\text { stimulants }(2.6 \%, 3.5 \%) \text {. Gender differences were not } \\
\text { observed. Lebanese were least likely to report non- } \\
\text { medical use. Nonmedical users mostly used the drugs for } \\
\text { their intended purpose (e.g., sleeping to help in sleep, } \\
\text { stimulants to increase alertness). Parents and pharmacists } \\
\text { (without a doctor's prescription) were the top two } \\
\text { sources of all medications but stimulants whereby } \\
\text { friends predominated. Diversion was observed in about } \\
20 \% \text { of the medical users. Lifetime marijuana users and } \\
\text { past year alcohol abusers were three times as likely to } \\
\text { use any prescription drug nonmedically. }\end{array}$ \\
\hline Lebanon & 19 & $\begin{array}{l}\text { Psychoactive } \\
\text { medications: }\end{array}$ & $\begin{array}{l}\text { CS, self- } \\
\text { administered } \\
\text { questionnaire }\end{array}$ & $\begin{array}{l}986 \text { school } \\
\text { students }\end{array}$ & $\begin{array}{l}\text { Almost half (46\%) had tried WTS compared to } 25 \% \text { who } \\
\text { had ever tried cigarettes. Lifetime prevalence estimates } \\
\text { of NMUPD were: pain relievers }(8.2 \%) \text {, } \\
\text { sedatives/tranquilizers (5.6\%), stimulants }(3.5 \%) \text {, } \\
\text { antidepressants }(2.5 \%) \text {, and sleeping pills }(2.3 \%) \text {. WTS } \\
\text { was associated with increased odds of sedatives/ } \\
\text { tranquilizer use (OR }=3.22,95 \% \text { CI: } 1.25,8.25) \text {, pain } \\
\text { reliever use (OR }=4.31,95 \% \text { CI: } 2.02,9.17) \text {, and } \\
\text { sleeping medication use (OR = 8.31, 95\% CI: } 2.37 \text {, } \\
29.20) \text {, controlling for sex, age, school type, and other } \\
\text { substance use. For cigarettes, the associations were } \\
\text { consistently either weaker or non-existent, except with } \\
\text { stimulant use (OR }=5.29,95 \% \text { CI: } 1.55,18.05) \text {. }\end{array}$ \\
\hline Pakistan & 23 & Self-medication & $\begin{array}{l}\mathrm{CS} \text {, self- } \\
\text { administered } \\
\text { questionnaire }\end{array}$ & $\begin{array}{l}268 \\
\text { university } \\
\text { students }\end{array}$ & $\begin{array}{l}\text { Out of } 268 \text { respondents (male }=61.6 \% \text {, female }= \\
38.6 \%), 138 \text { were non-health professional students } \\
\text { whereas } 130 \text { were health professional students. The } \\
\text { prevalence of SM was } 95.5 \% \text {. Most common factor } \\
(45.7 \%) \text { responsible for SM was "low severity of } \\
\text { disease". Most common symptom }(50.8 \%) \text { that caused } \\
\text { SM and stocking of medications was "storage of } \\
\text { medications for multi purposes". Some respondents } \\
(22.7 \%) \text { got addicted due to SM. Most of the students } \\
\text { trust in allopathic medications system. }\end{array}$ \\
\hline Pakistan & 24 & Benzodiazepine & $\begin{array}{l}\text { CS, pretested } \\
\text { questionnaire }\end{array}$ & $\begin{array}{l}749 \\
\text { participants } \\
\text { from } \\
\text { households }\end{array}$ & $\begin{array}{l}\text { The overall percentage of benzodiazepine consumption } \\
\text { was estimated to be } 14 \% \text {. There were significantly more } \\
\text { benzodiazepine users in the peri-urban Sultanabad } \\
\text { community to the urban community of Garden (p-value } \\
=0.001) \text {. The mean age ( } \pm \text { SD) for users was } 51.3 \text { ( } \pm \\
15.6 \text { ) years compared to } 37.1 \text { ( } \pm 14.4 \text { ) years among non- } \\
\text { users. Bromazepam was the most widely used } \\
\text { benzodiazepine ( } 29 \%) \text {; followed by diazepam, with a } \\
\text { median duration on primary use being } 144 \text { weeks. The } \\
\text { adjusted logistic regression model revealed that } \\
\text { increasing age, location, female sex, unemployment and } \\
\text { psychiatric consultation were associated with increased } \\
\text { likelihood of benzodiazepine use. }\end{array}$ \\
\hline Pakistan & 27 & $\begin{array}{l}\text { Psychoactive } \\
\text { drugs: } \\
\text { Benzodiazepine }\end{array}$ & Case series & $\begin{array}{l}118 \text { adults at } \\
\text { clinics }\end{array}$ & $\begin{array}{l}\text { Over } 40 \% \text { of the study subjects were taking psychoactive } \\
\text { drugs without an advice from their doctor. In all, } 78 \% \\
\text { were taking psychoactive drugs for }>6 \text { months and } 67 \% \\
\text { were using these drugs on a regular basis. Over } 85 \% \\
\text { were using these for induction of sleep and } 59 \% \text { for } \\
\text { relaxation. Seventy-five percent of study participants } \\
\text { reported that they can afford these pills and over } 46 \% \\
\text { were able to get these drugs easily; significantly more } \\
\text { men compared to women (58\% vs. 39\%; difference of } \\
\text { proportion }=-19.7 ; 95 \% \text { CI = -37, }-1.5) \text {. All other } \\
\text { studied characteristics were equally distributed among } \\
\text { men and women. }\end{array}$ \\
\hline Pakistan & 26 & Benzodiazepine & $\begin{array}{l}\mathrm{CS}, \\
\text { structured } \\
\text { questionnaire }\end{array}$ & $\begin{array}{l}475 \text { patients } \\
\text { visiting Aga } \\
\text { Khan } \\
\text { hospital }\end{array}$ & $\begin{array}{l}\text { The results showed that majority of population was } \\
\text { aware of one or more Benzodiazepines }(80.4 \%) \text { and } \\
30.4 \% \text { had used them at some point in life. } 42.4 \% \text { of the } \\
\text { users had been using it for more than a year. Commonest } \\
\text { reason for use was sleep disturbance. Frequency of usage } \\
\text { was higher for females, married individuals, educated } \\
\text { (Grade } 1,2) \text {, high socioeconomic status and housewives. }\end{array}$ \\
\hline
\end{tabular}




\begin{tabular}{|c|c|c|c|c|c|}
\hline & & & & & $\begin{array}{l}\text { More }(59 \%) \text { were prescribed than not and of them most } \\
\text { by GP }(58.5 \%) \text {. Only } 36.5 \% \text { of them were particularly } \\
\text { told about the long-term addiction potential by the use of } \\
\text { these drugs. }\end{array}$ \\
\hline Pakistan & 25 & Benzodiazepine & $\begin{array}{l}\text { Retrospective } \\
\text { case report } \\
\text { analysis }\end{array}$ & $\begin{array}{l}447 \text { patients } \\
\text { admitted to } \\
\text { Aga Khan } \\
\text { hospital } \\
\text { between } \\
\text { Jan } 1989 \text { and } \\
\text { Dec } 1994\end{array}$ & $\begin{array}{l}\text { Of the } 329 \text { medication self-poisoning cases, } 84 \% \text { were } \\
\text { benzodiazepine overdoses. Diazepam was the preferred } \\
\text { drug in } 69 \% \text { of these cases, with majority ingesting } \\
\text { between } 20-30 \text { tablets of } 5 \text { mg each, } 44 \% \text { bought the } \\
\text { benzodiazepine over the counter (OTC) for the purpose } \\
\text { of overdose. The preference for benzodiazepines over } \\
\text { analgesics (as freely available) may be related to the } \\
\text { motives underlying parasuicide acts and their popularity } \\
\text { as 'sleeping pills' in Pakistan. }\end{array}$ \\
\hline Pakistan & 8 & Benzodiazepine & $\begin{array}{l}\text { Retrospective } \\
\text { case report } \\
\text { analysis }\end{array}$ & $\begin{array}{l}314 \text { cases over } \\
\text { period } 3.5 \\
\text { years } \\
\text { Jan } 1989-\text { Jun } \\
1992\end{array}$ & $\begin{array}{l}\text { Most of the subjects were young adults, with married } \\
\text { women representing the single largest group. Self- } \\
\text { poisoning with medication was the most common } \\
\text { method, and benzodiazepines the most frequently used } \\
\text { drug accounting for } 74 \% \text { of cases. Interpersonal conflict } \\
\text { with the opposite sex was the most common } \\
\text { precipitating cause. In Pakistani culture, marriage } \\
\text { appears to be a significant source of stress for women. }\end{array}$ \\
\hline Iran & 14 & $\begin{array}{l}\text { Anabolic } \\
\text { steroids }\end{array}$ & $\begin{array}{l}\text { CS, self- } \\
\text { administered } \\
\text { questionnaire }\end{array}$ & $\begin{array}{l}202 \text { body } \\
\text { builders in } \\
\text { clubs }\end{array}$ & $\begin{array}{l}\text { The frequency of anabolic steroid abuse was } 18.8 \% \text {. The } \\
\text { mean period of bodybuilding activity was significantly } \\
\text { higher in those used the anabolic drugs ( } 38.8 \text { months), } \\
\text { comparing to those did not use any drugs ( } 14.3 \text { months). } \\
\text { Oxymetholone was the most common drug used by } \\
\text { athletes ( } 42 \% \text { merely used Oxymetholone). The } \\
\text { frequency of anabolic steroids abuse was not related to } \\
\text { education and age of the bodybuilder athletes. }\end{array}$ \\
\hline Iran & 11 & $\begin{array}{l}\text { Anabolic } \\
\text { steroids }\end{array}$ & $\begin{array}{l}\text { Case-control } \\
\text { study }\end{array}$ & $\begin{array}{l}50 \text { athletic } \\
\text { drug users } \\
\text { with } \\
\text { reported use } \\
\text { as a case } \\
\text { group and } \\
50 \text { athletic } \\
\text { nonusers } \\
\text { and } 50 \\
\text { nonathletic } \\
\text { nonusers }\end{array}$ & $\begin{array}{l}\text { Our findings showed that athletic drug users had a lower } \\
\text { self-efficacy, more dysfunctional attitudes, and exhibited } \\
\text { external locus of control rather than control groups. They } \\
\text { were also more sensitive to psychological morbidity. } \\
\text { Most of relations were statistically significant. }\end{array}$ \\
\hline Iran & 28 & $\begin{array}{l}\text { Tramadol and } \\
\text { Codeine }\end{array}$ & $\begin{array}{l}\text { CS, self- } \\
\text { administered } \\
\text { questionnaire }\end{array}$ & $\begin{array}{l}537 \text { school } \\
\text { students } \\
\text { (selected by } \\
\text { cluster } \\
\text { sampling in } \\
2008-2009 \\
\text { scholar year }\end{array}$ & $\begin{array}{l}\text { Sixty cases (11.2\%) of students had at least one-time } \\
\text { substance abuse (including alcohol, cannabis, opium, } \\
\text { heroin, ecstasy). General prevalence of substance use } \\
\text { was shisha (qalian) smoking (43\%), cigarette }(21.8 \%) \text {, } \\
\text { codeine or tramadol tablet (13.2\%), alcohol }(9.9 \%) \text {. } \\
\text { Frequency of substance abuse in males }(18.9 \%) \text { was } \\
\text { significantly more than in females }(7.7 \% ; \text { p0.05). }\end{array}$ \\
\hline Iran & 32 & $\begin{array}{l}\text { Psychoactive } \\
\text { medications: }\end{array}$ & $\mathrm{CS}$ & $\begin{array}{l}\text { High school } \\
\text { students }\end{array}$ & $\begin{array}{l}\text { Rates of lifetime and daily use of prescription sedatives } \\
\text { (mostly benzodiazepines) were } 2.7 \% \text { and } 3.8 \% \text {, } \\
\text { respectively, in high school boys and } 4.4 \% \text { and } 0.44 \% \text {, } \\
\text { respectively, in girls in the Kerman study }\end{array}$ \\
\hline Iran & 22 & Tramadol & $\begin{array}{l}\text { CS, } \\
\text { questionnaire } \\
\text { filled by } \\
\text { interviewer }\end{array}$ & $\begin{array}{l}162 \text { patients } \\
\text { who had } \\
\text { sought } \\
\text { tramadol } \\
\text { from a } \\
\text { pharmacy }\end{array}$ & $\begin{array}{l}\text { Of } 162 \text { patients, } 92(56 \%) \text { patients did not have a } \\
\text { prescription. At least } 103(64 \%) \text { patients reported criteria } \\
\text { for addiction (i.e., for feeling of psychological wellbeing, } \\
\text { unable to cease taking the drug, more than two weeks of } \\
\text { tramadol use). In total, } 145(89 \%) \text { patients were aged } \\
\text { younger than } 30 \text { years, and } 90(55 \%) \text { patients were aged } \\
\text { younger than } 18 \text { years. More than } 63 \% \text { of patients } \\
\text { reported a history of addiction or drug abuse. Most of the } \\
\text { patients with no prescription ( } 88 \%) \text { had abuse/addiction } \\
\text { criteria }\end{array}$ \\
\hline Iran & 29 & Tramadol & $\mathrm{CS}$ & $\begin{array}{l}36 \text { patients } \\
\text { referred to } \\
\text { the addiction } \\
\text { unit in Ibn- } \\
\text { Rushed }\end{array}$ & $\begin{array}{l}78 \% \text { were males and } 22 \% \text { were females. Their age was } \\
16-57 y \text { (mean } 27 y \text { ). } 90 \% \text { of the sample was on Tramadol } \\
\text { alone and } 10 \% \text { on polydrugs. About } 92 \% \text { of them were } \\
\text { iatrogenic abusers. Most of the patients were without } \\
\text { previous history of drug abuse. More than one fifth of }\end{array}$ \\
\hline
\end{tabular}




\begin{tabular}{|c|c|c|c|c|c|}
\hline & & & & $\begin{array}{l}\text { Mental } \\
\text { Teaching } \\
\text { Hospital }\end{array}$ & the patients had at least one seizure. \\
\hline Iran & 9 & Tramadol & $\begin{array}{l}\text { Phase } 1 \\
\text { Prospective } \\
\text { study }\end{array}$ & $\begin{array}{l}1894 \text { school } \\
\text { students }\end{array}$ & $\begin{array}{l}\text { Prevalence of lifetime tramadol misuse was } 4.8 \% \text {. } \\
\text { Adjusted OR of tramadol misusers with substance abuse } \\
\text { was: } 2.2 \text { with alcohol, } 5 \text { for cannabis, } 8.9 \text { for ectasy and } \\
2.3 \text { for opium, } 0.5 \text { for methamphetamines. Tramadol } \\
\text { could be related factor or cofactor for alcohol, cannabis } \\
\text { and ectasy use. }\end{array}$ \\
\hline Iran & 21 & Tramadol & $\begin{array}{l}\text { CS, interview } \\
\text { using } \\
\text { questionnaire }\end{array}$ & $\begin{array}{l}480 \\
\text { consecutive } \\
\text { patients } \\
\text { presenting } \\
\text { with pain } \\
\text { visiting } 10 \\
\text { clinics in } \\
\text { Zahedan. }\end{array}$ & $\begin{array}{l}\text { Prevalence of opioid use was } 28.5 \% \text { in patients } \\
\text { presenting with pain. No significant relationship between } \\
\text { opioid use and chronic pain (> } 6 \text { months). Significant } \\
\text { relationship with opioid use with } 5 \text { factors: previous } \\
\text { opioid use by friends ( } 72.9 \% \text { vs } 20.4 \% \text { without friends), } \\
\text { Occupation ( } 58.5 \% \text { private sector/self-employed vs } \\
17.4 \% \text { housewives), cigarette smoking ( } 60.8 \% \text { vs } 21.8 \% \\
\text { not smoking), consultation for a psychological problem } \\
\text { ( } 38.3 \% \text { vs } 23.3 \% \text { without), and death of a spouse ( } 60 \% \\
\text { vs } 26.1 \% \text { without). }\end{array}$ \\
\hline
\end{tabular}

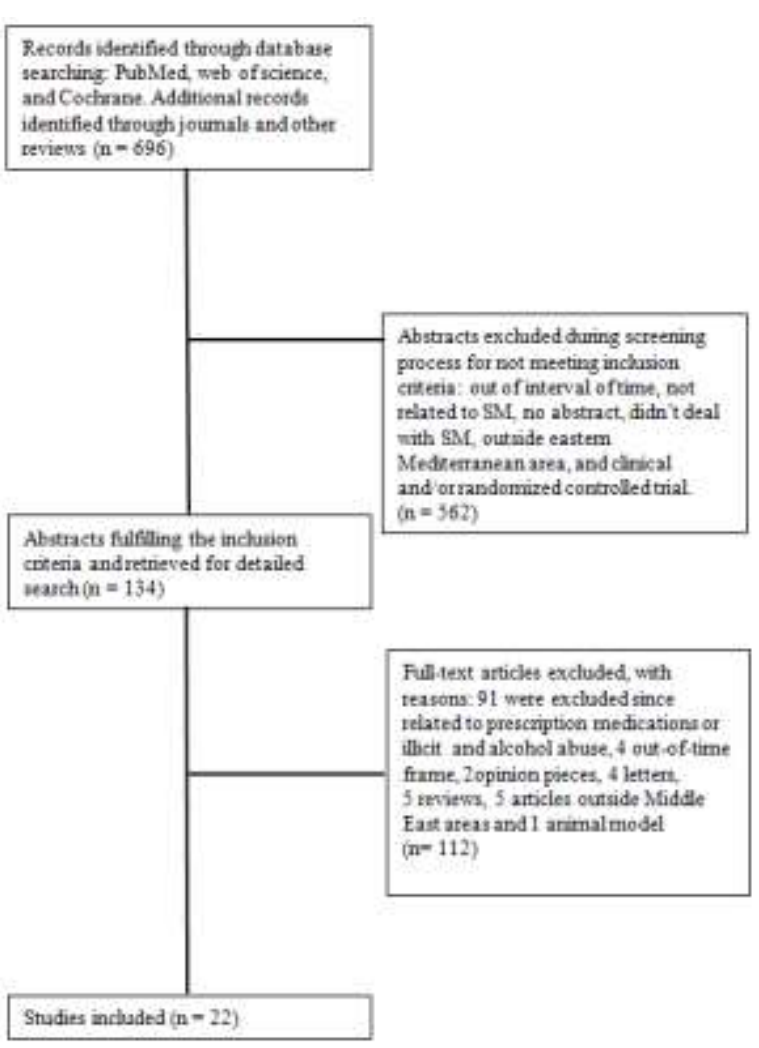

Figure 1: Selection of articles.

\section{Study characteristics}

The studies in the 22 publications differed substantially in sample size, recall period, and location. These studies reviewing overall prevalence, frequencies and pattern of SM misuse originated from different countries: Iran $(n=6)$, Pakistan $(n=6)$, Jordan $(n=2)$, Lebanon $(n=3)$, Egypt $(n=2)$, Iraq $(n=2)$, and Palestine $(n=1)$. Most studies were cross-sectional (CS) in nature except for 1 case series, 2 retrospective case report analyses, 1 prospective study, 1 qualitative study, and 1 case control study. ${ }^{8-11,25,27}$ Most of the studies used self-administered questionnaires or face to face interviews for data collection or mixed data collection techniques.

\section{Definitions of SM abuse}

Some articles did not distinguish between misuse and abuse as separate problems, although some attempts to do this were identified in the literature. Two studies referred to terms of OTC medication abuse and/or misuse and they used these terms uniquely. ${ }^{1,12}$ The term abuse was also described as frequent use of OTC medications. It also referred to nonmedical use of prescription medication. $^{11,13-21}$

Moreover, the terminology of abuse was not also distinguished from the terms addiction or dependence. For example, tramadol addiction symptoms were deemed to be increased tramadol dosage or continuing its use without a physician's permission, inability to stop using the drug or to decrease the dose, or feeling "incomplete" upon its withdrawal. ${ }^{22}$

\section{Scale of SM abuse}

Methods used to describe the extent of SM abuse varied. This variety is due to the use of different methods and data sources. Several studies relied on the perception of pharmacists (in Jordan and Palestine studies), whilst others relied on sampling the public, pharmacy customers or among university or school students. Others were from hospitals (e.g. in Pakistan), and self-reported abuse from specific groups such as gym club users (in Jordan and Iran).

The heterogeneous nature of these data sources makes assessing the international scale of SM abuse and between countries comparisons difficult. For example, studies based on pharmacists' perceptions appeared to generate varied descriptions of medicines that may be 
abused. The situation in Jordan was studied by AlbsoulYounes et al., who found that $94.1 \%$ of pharmacists suspected some abuse or misuse of OTC medications, and a mean estimate of "abusers" visiting each pharmacy in the last 3 months was 18.6 for regular customers, and 15.4 for new customers. ${ }^{1}$ Another similar study was conducted in Palestine by Swaileh et al based on perception of community pharmacists. Swaileh et al reported that $66 \%$ of community pharmacists believe that there is an increase in misuse/abuse of OTC products. ${ }^{12,13}$ Ullah showed that some students $(22.7 \%)$ in Pakistan became addicted because of $\mathrm{SM}^{23}$

Albsoul-Younes et al. reported that Jordanian pharmacists perceived the majority of abusers to be 2650-year-old males. ${ }^{1}$ Similarly, Sweileh et al. reported pharmacists as perceiving males to be more likely abusers than females in all categories except laxatives, in the 20 40-year-old age range. ${ }^{13}$

\section{Self-medications implicated in abuse}

OTC medications implicated in misuse and abuse belong to different groups: Psychoactive medications including: tramadol $^{20-22}$, Benzodiazepines ${ }^{1,8,24-26}$, Tramadol ${ }^{9,10}$ and Psychoactive medications. ${ }^{17-19,27}$ Codeine based products $^{28}$, Anabolic steroids ${ }^{11,14,15}$, and cough medications $^{1,12,28}$ or laxatives. ${ }^{1}$

These OTC medications were identified in different Eastern Mediterranean countries related to different pharmacologic groups in different settings (Table 2).

\section{Psychoactive medicines}

Abuse or nonmedical use of psychoactive medicines is highly prevalent in the Eastern Mediterranean area. The Psychotropic medicines frequently self-medicated include narcotic pain killers, tranquilizers, stimulants, and sedatives. ${ }^{17,18}$ Psychotropic medicines have been reported to be abused for pain, anxiety, insomnia, obesity, and enhancing academic performance or for getting high. ${ }^{17-}$ 19,27 Nonmedical users mostly used these drugs for sleeping disturbance to help in sleep or relax, and stimulants to increase alertness. ${ }^{18,27}$

Benzodiazepines were commonly cited by pharmacists In Jordan as being abused, as regulations restricting their supply were not always enforced. ${ }^{1}$ Zabihi reported that $44 \%$ of people bought benzodiazepine for the purpose of overdose. ${ }^{22}$ Others may use diazepam as a preferred drug due to their motives underlying parasuicide as reported in Pakistan. In $42 \%$ of cases, the drugs were available in the subject's home. ${ }^{8}$ Self-poisoning cases were in $84 \%$ due to benzodiazepine overdoses. ${ }^{8,25}$ In Pakistan, the life time prevalence of benzodiazepine use was reported to be $30.4 \%$; $42.4 \%$ of the users had been using it for more than a year. ${ }^{26}$ Bromazepam was the most widely used benzodiazepine (29\%). Rates of lifetime and daily use of prescription sedatives (mostly benzodiazepines) were
$2.7 \%$ and $3.8 \%$, respectively, in high school boys and $4.4 \%$ and $0.44 \%$, respectively, in girls in the Kerman study. ${ }^{22}$ Lifetime medical and nonmedical prevalence of medications were (respectively): pain $(36.9 \%, 15.1 \%)$, anxiety $(8.3 \%, 4.6 \%)$, sleeping $(6.5 \%, 5 / 8 \%)$ and stimulants $(2.6 \%, 3.5 \%)^{19}$.

Codeine and Tramadol can be easily obtained without prescription from community pharmacies in some countries even though they should only be dispensed as prescription medicines. The prevalence of Tramadol misuse among Iranian students was $4.7 \% .^{9}$ In the Zanjan study lifetime use rates for narcotic drugs, including codeine and tramadol, were $9.5 \%$ among high school boys and $16.8 \%$ among girls. ${ }^{28}$ Momtazi reported that the general prevalence of codeine or tramadol tablet possession among school students was $13.2 \% .^{28}$ Tramadol was the most commonly used pharmaceutical drug among youths in Egypt. ${ }^{10}$ Ghandour showed that psychoactive pain relievers ranked the highest, and stimulants the lowest, both medically and non-medically among university students. ${ }^{18}$ Long-term misuse of opioids was associated with increased risk for substance abuse. Tramadol could be a related factor or cofactor for alcohol, cannabis and Ecstasy use. ${ }^{9}$ Most patients reported a history of addiction or drug abuse. ${ }^{22}$ Prevalence of opioid use was $28.5 \%$ in patients presenting with pain, with no significant relationship between opioid use and chronic pain (>6 months). ${ }^{21}$

\section{Anabolic steroids}

In Amman, 31 (8.8\%) gym club clients admitted to using 21 anabolic steroids and other hormones (e.g., growth hormone and thyroxine) to increase muscular power or build muscle mass. ${ }^{15}$ The majority of participants were males $(75.6 \%)$ and between 19 and 32 years of age.

In Iran, lifetime anabolic use was $11.0 \%$ among male students and $1.8 \%$ among girls. Shakeri et al have shown that 11 to 20 -year-old athletes who use anabolic steroids had a lower sense of self-efficacy and a more dysfunctional attitude than nonusers. ${ }^{11}$ Sepehri et al. showed that $23.7 \%$ of bodybuilding athletes under the age of 20 had used anabolic steroids, mostly oxymetholone. ${ }^{14}$ Oxymetholone was the most common drug used by athletes $(42 \%){ }^{14}$

\section{Cough/cold products and laxatives}

Over the counter medicines like cough syrup were mentioned occasionally and only by boys as abused medications. ${ }^{10} 94.1 \%$ of pharmacists suspected that some level of abuse/misuse occurred in their pharmacy, which was highest for decongestants, cough/cold preparations. ${ }^{1}$ Swaileh et al reported that antitussives, analgesics, antihistamines, and laxatives were identified by pharmacists as misused and abused medications. ${ }^{12}$ 


\section{Sources and reasons for SM abuse}

Medication abuse is due to easy accessibility from pharmacies without prescription. ${ }^{1}$ Over $46 \%$ of study participants in Pakistan reported that they were able to get these drugs easily. ${ }^{27}$ Moreover, $56 \%$ of patients requesting tramadol did not have a prescription. ${ }^{23}$ In $42 \%$ of cases the drugs were available in the subject's home. ${ }^{8}$

Zabihi reported that $88 \%$ of the patients requesting tramadol in community pharmacies without prescription had abuse/addiction criteria. ${ }^{22}$ Poor knowledge is found to be an important factor for SM abuse. Most common symptom (50.8\%) that caused SM and stocking of medicines was storage of medicines for multiple purposes $(50.8 \%){ }^{23}$ More tramadol users than non-users tended to see tramadol consumption as either harmless or even useful. ${ }^{17}$ Only $36.5 \%$ of patients in Pakistan were told about the long-term addiction potential of these drugs. ${ }^{26}$ Friends are an important source for such misuse, where peer pressure from friends, or having a family member who used them, stood out as the most common reason to start and continue using substances. ${ }^{10,17,18}$

Gender differences were observed in abuse of psychotropic medications. Female sex was associated with increased likelihood of benzodiazepine use. ${ }^{24,26}$ However, the percentage of tramadol consumption was higher in males (78\%) than in females $(22 \%)$ in the Iraqi community. ${ }^{29}$ Abuse of analgesics is considered as risky behaviour and is initiated during early adolescence, particularly between 12 and 16 years. ${ }^{17}$ The mean age was 16.3 years among Iranian students and was 27 years among Iraqi community. ${ }^{9,29}$ In the Babol study $89 \%$ patients were aged younger than 30 years, and 55\% patients were aged younger than 18 years. ${ }^{22}$ However, Iqbal found that benzodiazepine users were older compared to the non-users. ${ }^{24}$

The frequency of psychotropic medications abuse was mostly related to low educational level and socioeconomic status. ${ }^{17,26}$ Cigarette or water pipe smoking was associated with increased odds ratio of sedatives/tranquilizer use and sleeping medication use. ${ }^{19,21}$ Abuse is also related to occupation, where housewives have more risk for abuse than employed individuals. $^{21,26}$

\section{Effects related to SM abuse}

A range of problems and harms associated with OTC medication abuse have been identified, related to pharmacological or psychological effects of the drug that is abused. Both lead to concerns about overdoses of medication, reported as poisoning behavior.

Wazaify reported that $9.6 \%$ participants experienced adverse effects with anabolic steroids, the majority of which were: tachycardia, palpitations, hypertension, priapism, testicular atrophy, renal, and psychological problems. ${ }^{15}$ Moreover, Shakeri et al showed that athletic drug users had a lower self-efficacy, more dysfunctional attitudes, and exhibited external locus of control. ${ }^{11}$ In addition, they were also more sensitive to psychological morbidity.

More than one fifth of the tramadol abusers had had at least one seizure. ${ }^{29}$ In Pakistan, data from hospital records show that of 329 medications self-poisoning cases, $84 \%$ were benzodiazepine overdoses. Diazepam was the preferred drug in $69 \%$ of these cases, with a majority ingesting between $20-305 \mathrm{mg}$ tablets. $44 \%$ had bought the benzodiazepine for the purpose of overdose. ${ }^{25}$

\section{Strategies to limit misuse and abuse}

Studies that include strategies to limit misuse and abuse are scarce in the Middle East. Only two studies have reported strategies to limit such practice. The studies that surveyed pharmacists sought practical strategies and a number of common approaches to limit misuse and abuse. These included advising customers to the abuse potential of products, refusing sales, requesting for prescriptions, hiding products from regular shelf, claiming products were not in stock, calling their doctor to verify, and supplying only limited amounts. ${ }^{1,30}$

\section{DISCUSSION}

Abuse behavior is widely present in the Middle East. This review summarizes different drugs involved in SM abuse and their prevalence in different study settings. These findings are consistent with other studies performed in developed countries, which have highlighted a high prevalence of OTC abuse. For example, Cooper R suggested medications such as stimulants, tramadol, sedatives, cough products and codeine based analgesics as being liable to abuse. ${ }^{6}$ Another study of Tulare County, California, Drug Court clients found that $16.2 \%$ admitted to abusing OTC medications, mostly ephedrine and other stimulants. $^{4}$

Abuse behavior could be widely present due to easy availability of such medicines without prescription in community pharmacies. Throughout the world, problematic use of drugs containing substances with psychoactive properties used for SM has been recognized as an important issue in community pharmacies, particularly for opioids, antihistamines with sedative properties, and sympathomimetics. ${ }^{31}$ This is applicable also for psychoactive medicines, benzodiazepines and anabolic steroids. Abuse is found to be a common behavior among adults and adolescents. Apparently, the uncontrolled consumption and lack of monitoring of consumption of medications is an important reason for abuse of SM. Friends or peer pressure were also important sources of self -medication abuse. The absence of medical supervision coupled with motivations such as "to get high" renders this issue a high priority for national 
awareness. We found no evidence-based interventions to limit misuse.

There is a clear problem of medication abuse in the Middle East. There is a tension between giving easy access to OTC medicines for self-medication where it is easy and desirable, and the risk of such products being abused. Quick interventions for controlling the use of SM and restricting the sales of other medicines as opioids, anabolic steroids, psychoactive medications and codeine containing products should be promising in this field. There is often a lack of awareness and educational programs concerning SM abuse. Education of health providers and consumers is also important to emphasize the correct use of OTC medicines.

Our results are limited by the heterogeneity of the data. Studies used different methods for data collection, which limits comparability between studies. Data based on qualitative methods are scarce; with only one identified study. ${ }^{10}$ The absence of qualitative data suggests these studies were structured survey designs. The use of retrospective case report analysis, such as those obtained from hospital centers in various reports as those conducted in Pakistan, and using details of patients attending these centers offers potentially more statistically robust cases. ${ }^{8,25}$ However, such data did not distinguish between prescription and OTC obtained medicines. Studies done based on pharmacists' perceptions provide more subjective data although they have high response rate. ${ }^{1,30}$

No clear patterns relating to those affected or their experiences were identified. However, several study designs have involved sampling those suspected of abusing medicines at targeted settings as gym clubs and body building clubs. ${ }^{11,14,15}$ These studies represent less subjective accounts of the problem but are specific to certain groups.

In addition, such research may not be easily accessible: some databases were not accessible, nor was unpublished data. The lack of standardization of term, especially the distinction between abuse, misuse, dependence and addition contributed to the confusion.

\section{CONCLUSION}

This review shows that SM abuse involving a range of medicines constitutes a public health problem in the Middle East. It also shed lights on the importance of controlling the use of medicines in the Middle East and the availability of restricted drugs. However, much research remain to be done on SM abuse in Eastern Mediterranean countries, to quantify the prevalence of abuse, report harms and evaluate interventions. These findings also signal the immediate need to raise awareness and education among adolescents, parents and health professionals, and to reinforce relevant policies. In addition, quick interventions are also needed to limit the expansion of SM behaviour in this area. There is clearly a need for a coordinated effort to train researchers in the field, and conduct standardized studies to measure the extent and the effects of self-medication abuse in the Middle East. From these, the obviously necessary evidence-based efforts to limit and control such abuse can be derived.

\section{Funding: No funding sources Conflict of interest: None declared Ethical approval: Not required}

\section{REFERENCES}

1. Albsoul-Younes A, Wazaify M, Yousef AM, Tahaineh L. Abuse and misuse of prescription and nonprescription drugs sold in community pharmacies in Jordan. Subst Use Misuse. 2010;45(9):1319-29.

2. Blenkinsopp A, Bradley C. Patients, society, and the increase in self-medication. BMJ. 1996;312(7031):629-32.

3. Hughes GF, McElnay JC, Hughes CM, McKenna P. Abuse/misuse of non-prescription drugs. Pharm World Sci. 1999;21(6):251-5.

4. Lessenger JE, Feinberg SD. Abuse of prescription and over-the-counter medications. J Am Board Fam Med. 2008;21(1):45-54.

5. McCabe SE, Teter CJ, Boyd CJ. Medical use, illicit use, and diversion of abusable prescription drugs. $\mathrm{J}$ Am Coll Health. 2006;54(5):269-78.

6. Cooper RJ. Over-the-counter medicine abuse - a review of the literature. J Subst Use. 2013;18(2):82107.

7. Kardas P, Devine S, Golembesky A, Roberts C. A systematic review and meta-analysis of misuse of antibiotic therapies in the community. Int $\mathbf{J}$ Antimicrob Agents. 2005;26(2):106-13.

8. Khan MM, Islam S, Kundi AK. Parasuicide in Pakistan: experience at a university hospital. Acta Psychiatr Scand. 1996;93(4):264-7.

9. Nazarzadeh M, Bidel Z, Carson KV. The association between tramadol hydrochloride misuse and other substances use in an adolescent population: Phase I of a prospective survey. Addict Behav. 2014;39(1):333-7.

10. Loffredo CA, Boulos DN, Saleh DA, Jillson IA, Garas M, Loza N, et al. Substance use by Egyptian youth: current patterns and potential avenues for prevention. Subst Use Misuse. 2015;50(5):609-18.

11. Shakeri J, Parvizifard A, Sadeghi K. Cognitive correlation and psychological morbidities of doping in athletes in Kermanshash, Iran. Iran J Psychiatry behav Sci. 2009;3:81-8.

12. Sweileh W. Self-Medication and Over-The-Counter Practices: A Study in Palestine. J Al-Aqsa Unv. 2004;8:1-9.

13. Sharifi A, Sharifi H, Karamouzian M, Mokhtari M, Esmaeili HH, Nejad AS, et al. Topical ocular anesthetic abuse among Iranian welders: time for 
action. Middle East Afr J Ophthalmol. 2013;20(4):336-40.

14. Sepehri G, Mousavifard M, Sepehri E. Frequency of anabolic steroids abuse in bodybuilder athletes in Kerman city. Addict Health. 2009;1:25-30.

15. Wazaify M, Bdair A, Al-Hadidi K, Scott J. Doping in gymnasiums in Amman: the other side of prescription and nonprescription drug abuse. Subst Use Misuse. 2014;49(10):1296-302.

16. Cheaito L, Azizi S, Saleh N, Salameh P. Assessment of self-medication in population buying antibiotics in pharmacies: a pilot study from Beirut and its suburbs. Int J Public Health. 2014;59(2):319-27.

17. Soueif MI, Youssuf GS, Taha HS, Moneim HA, Sree OA, Badr KA, et al. Use of psychoactive substances among male secondary school pupils in Egypt: a study on a nationwide representative sample. Drug Alcohol Depend. 1990;26(1):63-79.

18. Ghandour LA, El Sayed DS, Martins SS. Prevalence and patterns of commonly abused psychoactive prescription drugs in a sample of university students from Lebanon: an opportunity for cross-cultural comparisons. Drug Alcohol Depend. 2012;121(12):110-7.

19. Zahlan L, Ghandour L, Yassin N, Afifi R, Martins SS. Double trouble: Exploring the association between waterpipe tobacco smoking and the nonmedical use of psychoactive prescription drugs among adolescents. Drug Alcohol Depend. 2014;145:217-23.

20. Cottler LB, Ajinkya S, Goldberger BA, Ghani MA, Martin DM, $\mathrm{Hu} \mathrm{H}$, et al. Prevalence of drug and alcohol use in urban Afghanistan: epidemiological data from the Afghanistan National Urban Drug Use Study (ANUDUS). Lancet Glob Health. 2014;2(10):e592-600.

21. Rahimi-Movaghar V, Rakhshani F, Mohammadi M, Rahimi-Movaghar A. Opioid use in patients presenting with pain in Zahedan, Islamic Republic of Iran. East Mediterr Health J. 2004;10(1-2):82-9.

22. Zabihi E, Hoseinzaadeh A, Emami M, Mardani M, Mahmoud B, Akbar MA. Potential for tramadol abuse by patients visiting pharmacies in northern iran. Subst Abuse. 2011;5:11-5.

23. Ullah H, Khan SA, Ali S, Karim S, Baseer A, Chohan $\mathrm{O}$, et al. Evaluation of self-medication amongst university students in Abbottabad, Pakistan; prevalence, attitude and causes. Acta Pol Pharm. 2013;70(5):919-22.

24. Iqbal SP, Ahmer S, Farooq S, Parpio Y, Tharani A, Khan RA, et al. Benzodiazepine use among adults residing in the urban settlements of Karachi, Pakistan: a cross sectional study. Subst Abuse Treat Prev Policy. 2011;6:19.

25. Khan MM, Reza H. Benzodiazepine self-poisoning in Pakistan: implications for prevention and harm reduction. J Pak Med Assoc 1998;48(10):293-5.

26. Raoof M, Nawaz H, Nusrat R, Pabaney AH, Randhawa AR, Rehman R, et al. Awareness and use of Benzodiazepines in healthy volunteers and ambulatory patients visiting a tertiary care hospital: a cross sectional survey. PLoS One. 2008;3(3):e1804.

27. Ali NS, Khuwaja AK, Zafar AM. Characteristics of patients using psychoactive drugs in Karachi, Pakistan. Pharm World Sci. 2009;31(3):369-72.

28. Momtazi S, Nouhravesh M, Taremian F. A study of substance abuse and some related risk factors in Iranian high school students. In: NIDA International Forumed. 2009.

29. Lafta M. Tramadol dependence in addiction unit of Baghdad: A cross sectional study. European Psychiatry. 2011;26:27.

30. Sweileh WM, Arafat RT, Al-Khyat LS, Al-Masri DM, Jaradat NA. A pilot study to investigate overthe-counter drug abuse and misuse in Palestine. Saudi Med J. 2004;25(12):2029-32.

31. Matheson M, Bond CM, Pitcarin J. Misuse of overthe-counter medicines from community pharmacies: A population survey of Scottish pharmacies. Pharmaceutical Journal. 2002;269(7206):66-8.

32. Ziaadini H, Zarezadeh A, Heshmati F. The Prevalence rate of substance abuse and addiction and some relevant factors among junior and senior high school students in Kerman, Iran. J Kerman Univ Med Sci. 2006;13:84-94.

Cite this article as: Khalifeh MM, Moore ND,

Salameh PR. Self-medications with potential abuse

in the Middle East: a systematic literature review. Int J Basic Clin Pharmacol 2016;5:2298-2307. 